УДК 691.32

\title{
ОСОБЛИВОСТІ ТЕХНОЛОГІЇ ВИРОБНИЦТВА ЗАЛІЗОБЕТОННИХ ШПАЛ
}

Канд. техн. наук О.В. Романенко

ОСОБЕННОСТИ ТЕХНОЛОГИИ ПРОИЗВОДСТВА ЖЕЛЕЗОБЕТОННЫХ ШПАЛ

\section{Канд. техн. наук А.В. Романенко \\ PECULIARITIES OF MANUFACTURING TECHNOLOGY REINFORCED CONCRETE SLEEPERS}

Cand. of techn. sciences O.V. Romanenko

Виробництво залізобетонних шпал здійснюється в Украӥні за дуже енергоємною технологією, обумовленою застосуванням тепловологісної обробки шпал.

У роботі наведено статистичні дані використання режимів тепловологісної обробки на заводах ЗБШ Украӥни, щуо дає змогу визначити складову газу в собівартості шпали $і$ дає змогу визначити економічний ефект від впровадження особливо швидкотверднучого бетону при виробництві залізобетонних шпал.

Ключові слова: бетон, тепловологісна обробка, залізобетонна шпала, завод ЗБШ, газ, собівартість.

Производство железобетонных шпал осуществляется в Украине по очень энергоемкой технологии, обусловленной применением тепловлажностной обработки шпал.

B работе приведень статистические данные использования режимов тепловлажностной обработки на заводах ЖБШ Украины, позволяющие определить составляюшую газа в себестоимости шпаль и рассчитать экономический эффект от внедрения особо быстротвердеющего бетона при производстве железобетонных шпал.

Ключевые слова: бетон, тепловлажностная обработка, железобетонная шпала, завод ЖБШ, газ, себестоимость.

Production of concrete sleepers in Ukraine is at a very energy-intensive technologies due to the use of thermal-processing sleepers. Given the rise in prices of energy occurs in the recent times, the reduction of thermal-processing mode or full rejection of it is a very urgent task. The urgency of this problem has increased the need to increase the production of concrete sleepers in connection with the growing need of the Ukrainian railways in them.

The paper presents statistical data using modes of thermal-processing concrete othe cost of sleepers and allows the definition of the economic effect of the introduction of osoblivoshvidkotverdnuchogo concrete in the production of concrete sleepers

Keywords: concrete, reinforced concrete sleepers, gas, prime cost.

Вступ. При виробництві залізобетонних шпал та інших попередньо напружених залізобетонних конструкцій на підприємствах передаточну міцність зазвичай забезпечують за рахунок їх тепловологісної обробки (ТВО) парою, яка виробляється газовими котельнями.
Постановка проблеми у загальному вигляді та її зв'язок із важливими науковими та практичними завданнями. У статті, яка $\epsilon$ результатом досліджень кафедри БМКС УкрДАЗТ, аналізується доцільність заміни ТВО на заводах України 
іншими способами прискорення твердіння бетону.

Аналіз останніх досліджень та публікацій. Особливості технології виробництва залізобетонних шпал проаналізовані за результатами виконаних раніше обстежень заводів залізобетонних шпал: Гніванського ЗСЗБ, Київського ДЗЗБШ [1], Коростенського ЗЗБШ [2], Кременчуцького ЗЗБШ [3], Старокостянтинівського ЗЗБШ, в останньому 3 яких автор брав особисту участь.
Визначення мети та задачі дослідження. Основним завданням $є$ виявлення складової газу в собівартості виробництва залізобетонних шпал для визначення економічного ефекту від впровадження особливо швидкотверднучого бетону, розробленого на кафедрі БМКС УкрДАЗТ.

Основна частина дослідження. У табл. 1 наведено склади бетонів, які застосовуються на заводах ЗБШ (за результатами досліджень [1-3]).

Таблиця 1

Склади бетону, застосовувані підприємствами з виробництва залізобетонних шпал для досягнення потрібної передаточної міцності за даними робіт [1-3]

\begin{tabular}{|c|c|c|c|c|c|c|c|c|c|c|c|c|c|c|}
\hline \multirow[t]{2}{*}{ ЗЗБШ } & \multirow[t]{2}{*}{ Рік } & \multicolumn{2}{|c|}{$\begin{array}{c}\text { Дрібний } \\
\text { заповнювач }\end{array}$} & \multirow[t]{2}{*}{$\alpha_{\text {onm }}$} & \multirow[t]{2}{*}{$\mu_{\text {onm }}$} & \multicolumn{4}{|c|}{$\begin{array}{c}\text { Номінальний } \\
\text { склад бетону, } \\
\kappa \Gamma / \mathbf{m}^{3}\end{array}$} & \multirow[t]{2}{*}{$B / Ц$} & \multirow[t]{2}{*}{$\alpha$} & \multirow[t]{2}{*}{$\mu$} & \multirow[t]{2}{*}{$\begin{array}{c}\Delta \alpha, \\
\%\end{array}$} & \multirow[t]{2}{*}{$\begin{array}{c}\Delta \mu, \\
\%\end{array}$} \\
\hline & & $\begin{array}{c}\text { місце } \\
\text { видобування }\end{array}$ & $M_{\kappa}$ & & & Щ & $\Pi$ & $Ц$ & $B$ & & & & & \\
\hline $\begin{array}{c}\text { Гніванський } \\
\text { ЗСЗБ }\end{array}$ & 1998 & $\begin{array}{c}\text { Славутський } \\
\text { кар'єр }\end{array}$ & 2,55 & 1,23 & 1,74 & 1243 & 620 & 450 & 143 & 0,32 & 1,30 & 1,21 & 5,7 & -30 , \\
\hline $\begin{array}{c}\text { Київський } \\
\text { ДЗЗБШ }\end{array}$ & 2000 & $\begin{array}{c}\text { Київський } \\
\text { річковий } \\
\text { порт* }\end{array}$ & 1,47 & 1,10 & 2,69 & 1285 & 615 & 409 & 139 & 0,34 & 1,06 & 1,61 & $-3,6$ & -40 \\
\hline \multirow{2}{*}{$\begin{array}{c}\text { Коростен- } \\
\text { ський ЗЗБШ }\end{array}$} & \multirow[t]{2}{*}{2000} & $\begin{array}{c}\text { Київський } \\
\text { річковий } \\
\text { порт* }\end{array}$ & 1,48 & 1,13 & 2,23 & 1194 & 675 & 455 & 147 & 0,32 & 1,22 & 1,46 & 8,0 & $-34,5$ \\
\hline & & $\begin{array}{l}\text { Ігнатополь- } \\
\text { ський кар'єр }\end{array}$ & 2,05 & 1,20 & 1,74 & 1204 & 681 & 453 & 139 & 0,31 & 1,34 & 1,61 & 11,7 & $-7,5$ \\
\hline $\begin{array}{c}\text { Кременчуць- } \\
\text { кий ЗЗБШ }\end{array}$ & 2003 & $\begin{array}{c}\text { Кременчуць- } \\
\text { кий річковий } \\
\text { порт* }\end{array}$ & 1,75 & 1,18 & 1,37 & 1191 & 640 & 457 & 161 & 0,35 & 1,37 & 1,80 & 16,1 & 31,4 \\
\hline $\begin{array}{c}\text { Старокос- } \\
\text { тянтинів- } \\
\text { ський ЗЗБШ } \\
\end{array}$ & 2008 & $\begin{array}{l}\text { Ігнатополь- } \\
\text { ський кар’єр }\end{array}$ & 2,25 & 1,15 & 1,74 & 1250 & 585 & 464 & 160 & 0,34 & 1,15 & 1,76 & 0,0 & 1,1 \\
\hline
\end{tabular}

Примітка. * пісок річковий дніпровський.

У цілому технологія виробництва шпал відповідає загальноприйнятій технології виробництва збірного залізобетону [4-10]. Цехи, у яких виготовляють шпали, поділені на п'ять ділянок: арматурна; підготовки і оснащення форм; формувальна; ТВО; розпалублення, що передує вихідному контролю якості i передачі шпал на склад.

Найбільш енергоємним етапом виготовлення шпал $\epsilon$ ТВО, яка здійснюється в пропарювальних камерах ямного типу. Режими ТВО, які застосовувались на Гніванському ЗСЗБ, 
Київському ДЗЗБШ [1], Коростеньському З3БШ [2], Кременчуцькому З3БШ [3],
Старокостянтинівському ЗЗБШ, наведені на рис. $1-5$ і в табл. 2.

a)

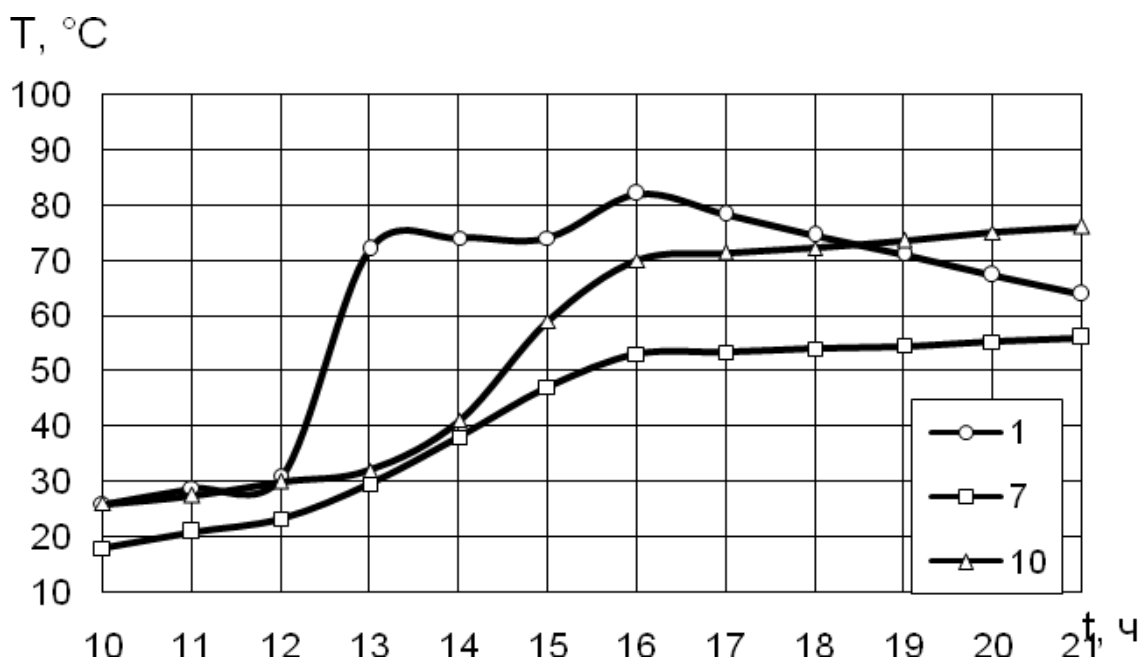

б)

$\mathrm{T},{ }^{\circ} \mathrm{C}$

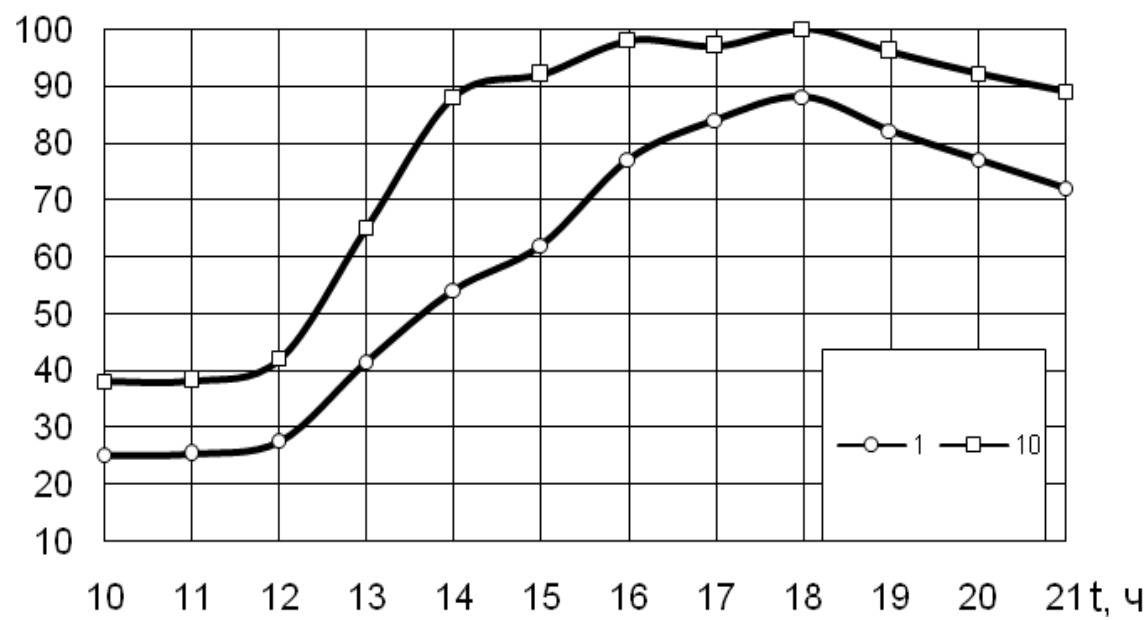

Рис. 1. Фактичні режими ТВО залізобетонних шпал на Гніванському ЗСЖБ: а - на лінії № 1; б - на лінії № 02 (цифрами позначені номери датчиків) 
a)

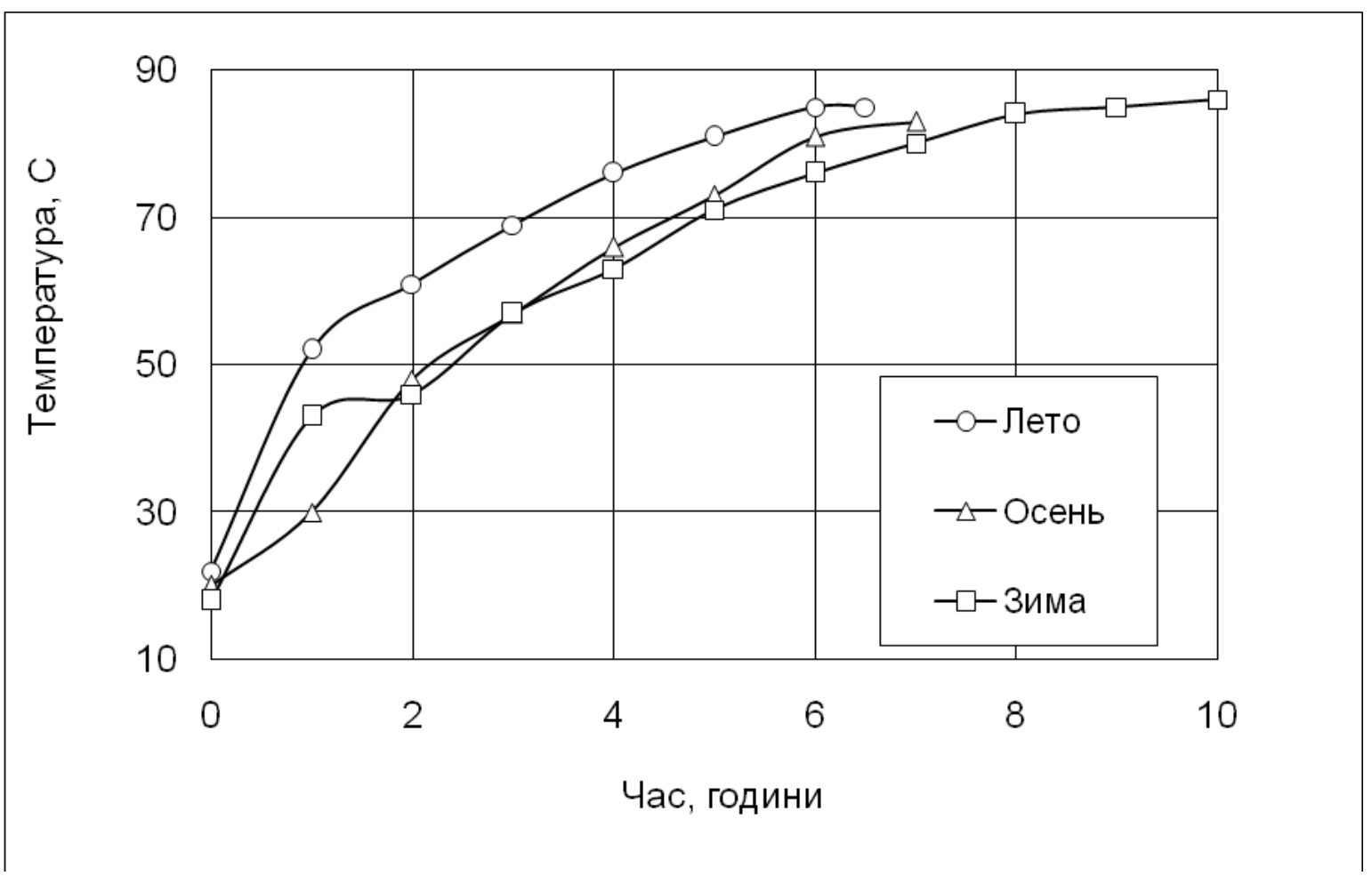

б)

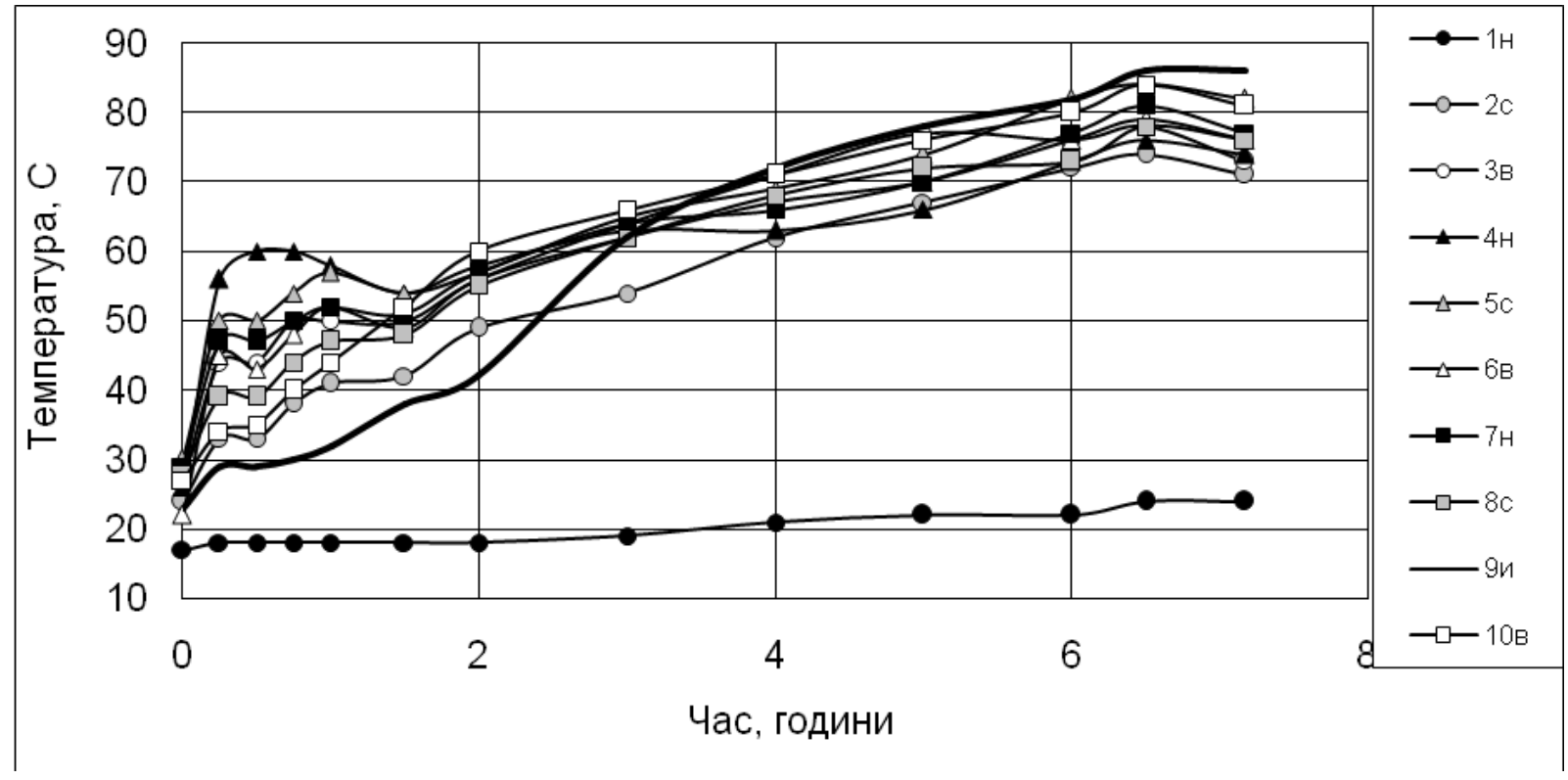

Рис. 2. Режими ТВО залізобетонних шпал на Київському ДЗЗБШ [1]:

a - за даними журналів ТВО, б - за результатами безпосередніх вимірів (цифрами позначені номери датчиків; н - датчик у нижній частині камери; з - датчик посередині висоти камери; в - датчик у верхній частині камери) 

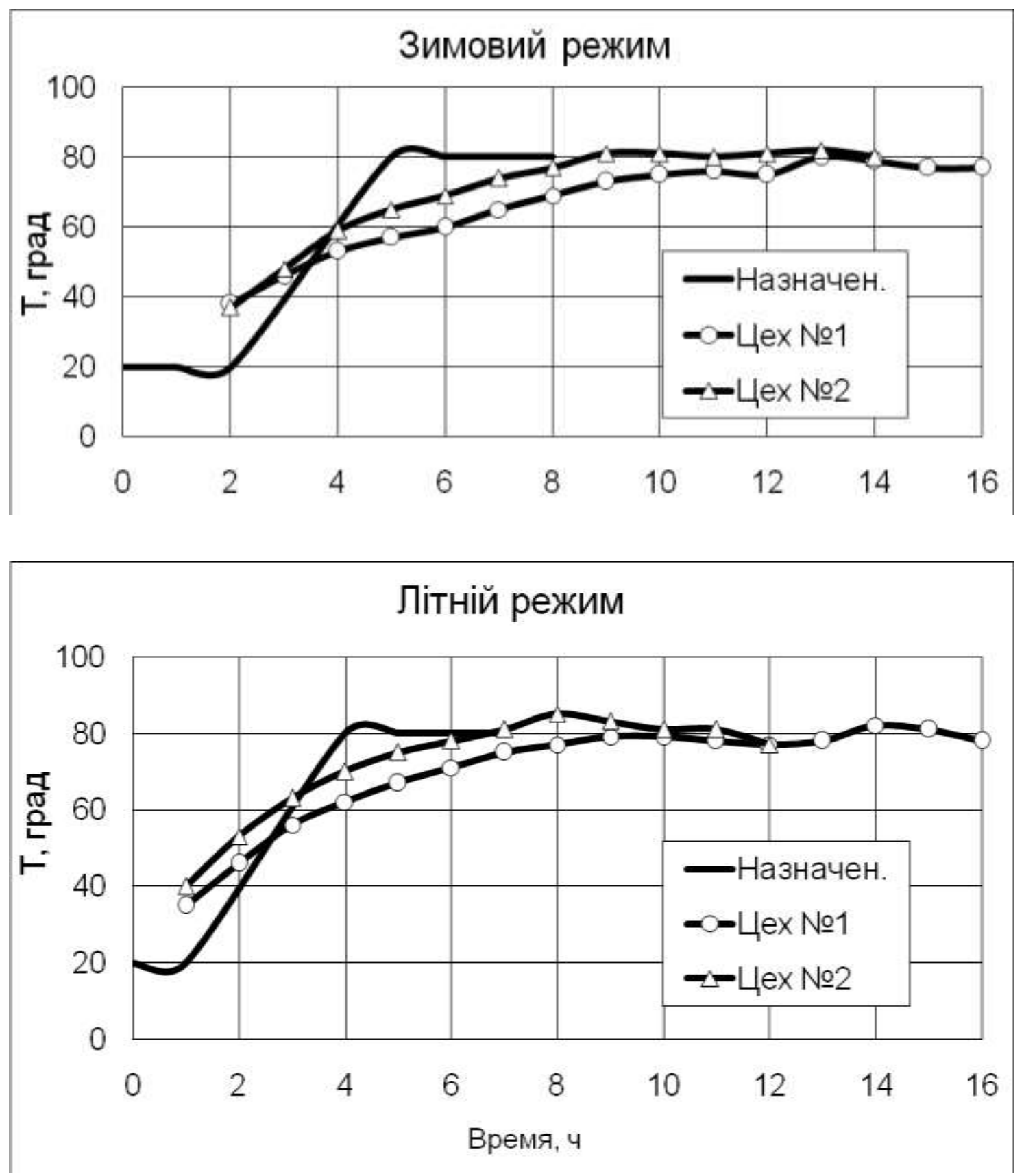

Рис. 3. Назначені і фактичні (за даними журналів ТВО для цехів № 1 i № 2) режими ТВО залізобетонних шпал на Коростеньському З3БШ [2] 

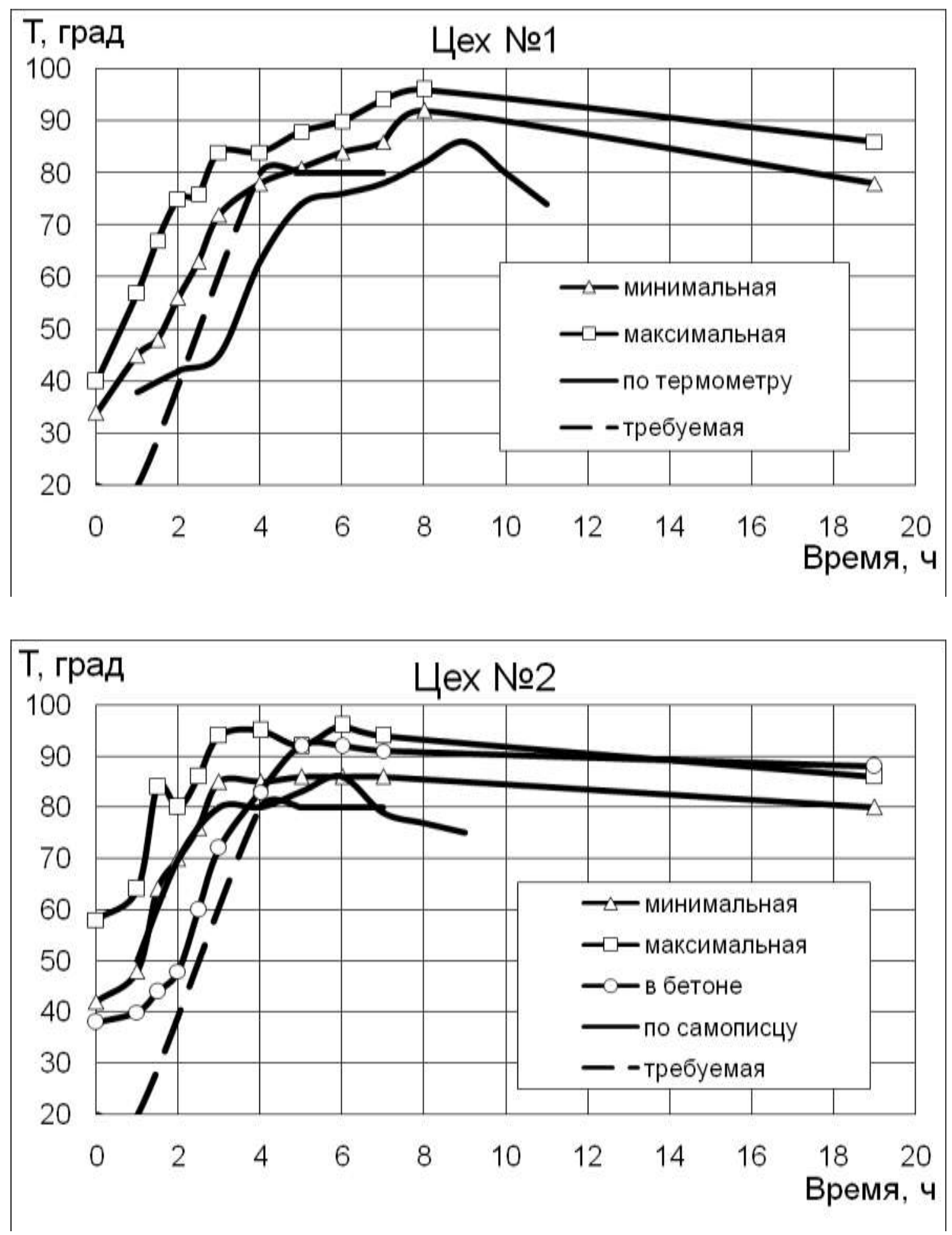

Рис. 4. Фактичні режими ТВО залізобетонних шпал у цехах № 1 та № 2 на Коростеньському З3БШ [3] 


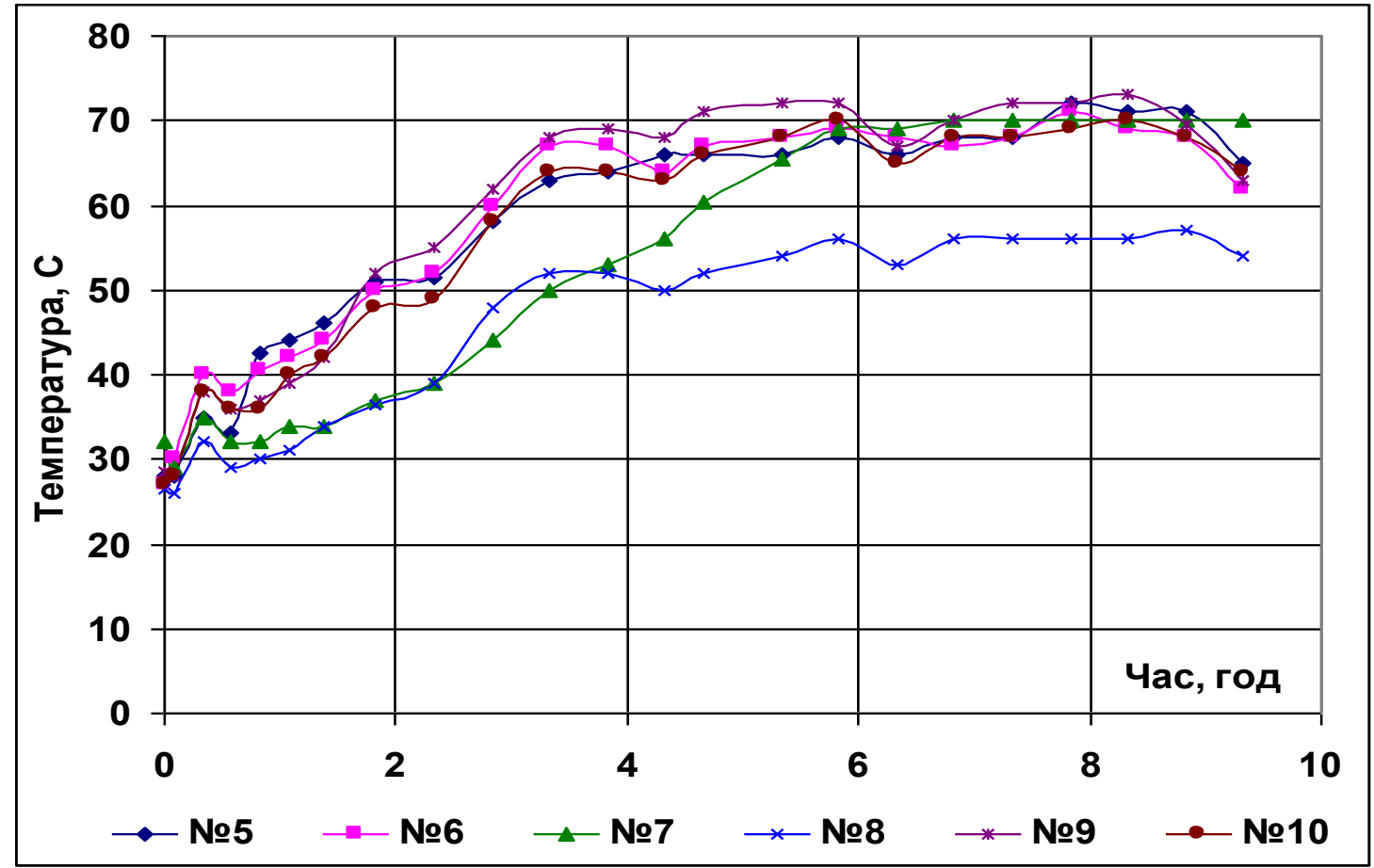

Рис. 5. Фактичні режими ТВО залізобетонних плит БМП на Старокостянтинівському ЗЗБШ (цифрами позначені номери датчиків)

Таблиця 2

Режими ТВО залізобетонних шпал на підприємствах України

\begin{tabular}{|c|c|c|c|c|c|}
\hline \multirow[b]{2}{*}{ Підприємство } & \multirow[b]{2}{*}{ Рік } & \multirow{2}{*}{ 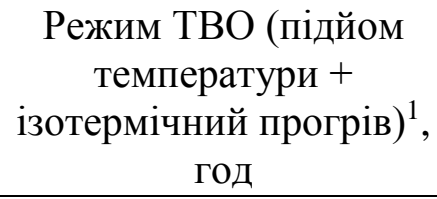 } & \multicolumn{2}{|c|}{ Температура, ${ }^{\circ} \mathrm{C}$} & \multirow{2}{*}{$\begin{array}{c}\text { Умовна } \\
\text { витрата } \\
\text { тепла, } \\
{ }^{\circ} \mathrm{C} \times \text { год }\end{array}$} \\
\hline & & & Діапазон $^{2}$ & Середня & \\
\hline Гніванський ЗСЖБ & 1998 & $\begin{array}{l}\text { літо } 6(4+2) ; \\
\text { зима } 9(4+5) \\
\end{array}$ & $70-100$ & 75 & 565 \\
\hline Київський ДЗЗБШ & 2000 & $\begin{array}{l}\text { літо } 6,5(6+0,5) ; \\
\text { зима } 8(6+2)\end{array}$ & $75-85$ & 80 & 460 \\
\hline Коростенський ЗЗБШ & 2000 & $8(4+4)$ & $80-95$ & 85 & 550 \\
\hline Кременчуцький ЗЗБШ & 2003 & $7(3+4)$ & & 90 & 360 \\
\hline $\begin{array}{c}\text { Старокостянтинівський } \\
\text { ЗЗБШ }\end{array}$ & 2008 & $9(3,5+5,5)$ & $55-75$ & 65 & 506 \\
\hline
\end{tabular}

Примітки: ${ }^{1}$ попередня витримка на всіх підприємствах - 2 - 3 год;

2 діапазон температури ізотермічного прогріву за обсягом камери.

Як бачимо, шпали піддаються досить інтенсивній ТВО з подачею пари від 6,5 до 9 год до забезпечення середньої температури ізотермічної витримки до $90{ }^{\circ} \mathrm{C}$. Пар виробляється газовими котельнями. Найбільш економічним був режим ТВО (умовна витрата тепла близько $460{ }^{\circ} \mathrm{C} \times$ год), застосовуваний на Київському ДЗЗБШ (на сьогодні шпали для залізниць не виробляс), який досягався тривалим 
повільним підйомом температури i коротким ізотермічним прогрівом. $\mathrm{y}$ цілому основний недолік ТВО - висока енергоємність, зокрема витрата газу газовими котельнями, найбільш розповсюдженими на заводах. Витрати газу можуть бути скорочені на декілька десятків відсотків за рахунок застосування інтенсивної циркуляції пароповітряної суміші в пропарюівальних камерах, компактних парогенераторів, розташованих безпосередньо біля камер. Проте, враховуючи подорожчання газу останніми роками в декілька разів, ці заходи хоча і $\epsilon$ доцільними, не можуть істотно знизити собівартість шпал.

У табл. 3 i на рис. 6 наведено результати розрахунку складової газу в собівартості однієї шпали за даними робіт [1-3] і відкритими даними про ціну на газ i курс долара США [11].

Таблиця 3

Збільшення складової газу в собівартості однієї залізобетонної шпали в період 2007 - 2012 pp.

\begin{tabular}{|c|c|c|c|c|}
\hline \multirow[b]{2}{*}{ Показник } & \multirow{2}{*}{$\begin{array}{c}\text { Одиниця } \\
\text { вимірювання }\end{array}$} & \multicolumn{3}{|c|}{ Кількість у цінах } \\
\hline & & $\begin{array}{l}\text { кінець } \\
2007 \text { р. }\end{array}$ & $\begin{array}{c}\text { початок } \\
2009 \text { р. }\end{array}$ & $\begin{array}{c}\text { початок } \\
2012 \text { p. }\end{array}$ \\
\hline Витрата газу на 1 м³ бетону & $\mathrm{M}^{3}$ & 32 & 32 & 32 \\
\hline Витрата газу на 1 м 3 бетону & шт. & 10 & 10 & 10 \\
\hline Витрата газу на 1 шпалу & $\mathrm{M}^{3}$ & 3,2 & 3,2 & 3,2 \\
\hline \multirow{2}{*}{ Ціна 1000 м газу } & дол. & 200,00 & & 412,5 \\
\hline & грн & & 2626,50 & \\
\hline Курс долара & грн & 5,10 & & 7,99 \\
\hline Ціна 1 м ${ }^{3}$ газу & грн & 1,02 & 2,63 & 3,30 \\
\hline Вартість газу на 1 шпалу & грн & 3,26 & 8,40 & 10,55 \\
\hline
\end{tabular}

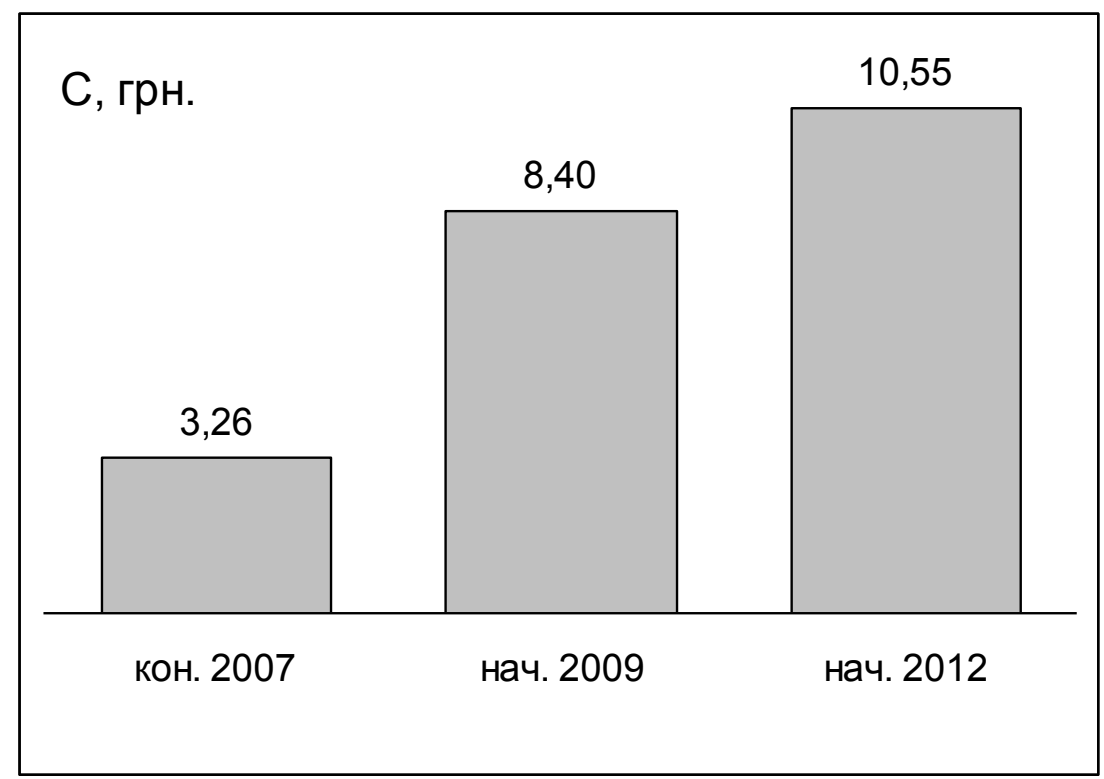

Рис. 6. Збільшення складової газу С в собівартості однієї залізобетонної шпали в період 2007-2012 pp. 
Як бачимо, складова газу в собівартості однієї залізобетонної шпали зросла 3 2007 по 2012 р. від 3,26 до 10,55 грн або в 3,24 разу, що підкреслює необхідність скорочення режиму ТВО або відмови від неї.

Висновки 3 дослідження i перспективи, подальший розвиток у даному напрямку. Встановлено, що тепловологісна обробка забезпечує досягнення необхідної передаточної міцності до розпалублення шпал, тобто через 10-12 год. Зменшити складову газу в собівартості шпали можливо шляхом зниження температури ізотермічної витримки і тривалості ТВО і, відповідно, скорочення витрати пари та газу на виготовлення шпал. При цьому для досягнення необхідної передаточної міцності через 10-12 год після формування доцільно застосувати інші технологічні способи прискорення твердіння бетону, наприклад модифікуючі добавки.

\section{Список використаних джерел}

1. Рекомендації 3 виготовлення залізобетонних шпал у відповідності до ТУ У 01116472.021-97 (для Київського експериментального заводу залізобетонних шпал) [Текст] / А.М. Плугін, О.А. Калінін, А.А. Плугін [та ін.] - Харків: ХарДАЗТ, 2000. - 58 с.

2. Рекомендації з удосконалення технології виробництва залізобетонних шпал у відповідності з ТУ У 01116472.021 (для Коростенського заводу залізобетонних шпал) [Текст] / А.М. Плугін, О.А. Калінін, А.А. Плугін [та ін.] - Харків: ХарДАЗТ, 2001. -123 с.

3. Заключення щодо відповідності вимогам ТУ У 01116472.021шпал залізобетонних попередньо напружених із зменшеною кількістю арматури для залізниць колії 1520 мм, що виробляються ЗАТ Кременчуцький ЗЗБШ-2 / А.М. Плугін, О.А. Калінін, А.А. Плугін [та ін.] - Харків: ХарДАЗТ, 2001. - 45 с.

4. Баженов, Ю.М. Технология бетонных и железобетонных изделий [Текст] / Ю.М. Баженов, А.Г. Комар. - М.: Стройиздат, 1984. - 672 с.

5. Руководство по технологии формования железобетонных изделий [Текст] / НИИЖБ. - М.: Стройиздат, 1977. - 96 с.

6. Пособие по технологии формования железобетонных изделий (к СНиП 3.09.01-85) [Текст] / НИИЖБ. - М.: Стройиздат, 1988. - 112 с.

7. Руководство по тепловой обработке железобетонных изделий [Текст] / НИИЖБ; ВНИИжелезобетон. - М.: Стройиздат, 1974. - 32 с.

8. Пособие по тепловой обработке железобетонных конструкций и изделий (к СНиП 3.09.01-85) [Текст] / ВНИИжелезобетон. - М.: Стройиздат, 1989. - 49 с.

9. ДБН А.3.1-7-96. Виробництво бетонних та залізобетонних виробів [Текст] / НДІБВ. К.: Укрархбудінформ, 1997. - 40 с.

10. Посібник до ДБН А.3.1-7-96. Виробництво бетонних та залізобетонних виробів [Текст] / НДІБВ. - К.: Укрархбудінформ, 1998. - 94 с.

11. Національний банк України: Офіційне Інтернет-представництво [Електронний pecypc]. - Режим доступу: http://www.bank.gov.ua/control/uk/index.

Рецензент д-р техн. наук, професор А.А. Плугін

Романенко Олександр Валерійович, канд. техн. наук, асистент кафедри буд. матеріалів, конструкцій та споруд

Української державної академиї залізничного транспорту. Тел.: (057) 730-10-63. E-mail: roma_kharkov83@mail.ru.

Romanenko Alexander V., cand. of techn. sciences, assistant of building materials, constructions and buildings department Ukrainian State Academy of Railway Transport. Tel: (057)730-10-63. E-mail: roma_kharkov83@mail.ru. 